\title{
O CHOURIÇO E A PATRIMONIALIZAÇÃO DAS COMIDAS DO SERTÃO: QUESTÕES, ENTRAVES E DESAFIOS $^{1}$
}

\section{CHOURIÇO AND FOOD HERITAGE FROM THE SERTÃO: ISSUES, OBSTACLES, AND CHALLENGES}

\section{Julie Cavignac}

julie.cavignac@ufrn.br

Professora Titular do Departamento de Antropologia da Universidade

Federal do Rio Grande do Norte

Orcid: https://orcid.org/0000-0003-0192-1103

\section{Maria Isabel Dantas}

beldantas2@gmail.com

Pesquisadora do Instituto Federal do Rio Grande do Norte

Orcid: https://orcid.org/0000-0002-0713-1391

\section{(a) $\mathbb{Q} \Theta($}

Esta obra está licenciada sob uma licença Creative Commons Attribution-NonCommercial-ShareAlike 4.0 International License.

\section{RESUMO}

No Seridó, a alimentação é objeto de patrimonialização desde 2010. Com o registro da Festa de Sant'Ana, foram planejadas ações visando a salvaguarda das práticas alimentares consideradas tradicionais, tal qual o saber-fazer das mestras de chouriço. Por outro lado, o crescimento do turismo, a gastronomização da comida regional e a promoção das marcas da "cultura rústica" por agentes políticos provocam um movimento de patrimonialização fora das agências estatais. Apesar da alimentação estar no cerne da questão, os instrumentos que foram implementados se revelam ineficazes, inexistentes ou não chegam ao conhecimento dos representantes das tradições culinárias. Longe de ser um vetor de reconhecimento, de desenvolvimento econômico ou de emancipação para as populações detentoras dos saberes, a patrimonialização parece ter um efeito contrário, pois reforça as barreiras sociais e raciais. Esta constatação é o ponto de partida de uma reflexão sobre os embates do patrimônio alimentar numa sociedade atravessada por tensões sociais e políticas, focada no passado colonial e que reelabora sua identidade no ato de comer.

Palavras-chave: patrimônio; gastronomização; festa de Sant'Ana; chouriço.

\section{ABSTRACT}

In Seridó, food has been the object of Geographical Indication of Provenance since 2010. With the registration of the Feast of Sant'Ana, actions 
were planned aimed at safeguarding traditional eating practices, such as the know-how of the mestras de chouriço. On the other hand, the growth of tourism, the "gastronomization" of regional food and the promotion of "rustic culture" brands by political agents provoke a movement of patrimonialization outside state agencies. Although food is at the heart of the matter, the instruments that have been implemented prove to be ineffective, non-existent or not known to representatives of culinary traditions. Far from being a vector of recognition, economic development or emancipation for knowledge-bearing populations, patrimonialization seems to have the opposite effect, as it reinforces social and racial barriers. This finding is the starting point for a reflection on the clashes of food heritage in a society struggling with social and political tensions, focused on the colonial past and re-elaborating its identity in the act of eatin.

Keywords: heritage; gastronomization; feast of Sant'ana; chouriço.

\section{INTRODUÇÃO}

A festa de Sant'Ana de Caicó, "capital" do Seridó potiguar², foi registrada no livro das celebrações, em 2010, pelo órgão responsável, o Instituto do Patrimônio Histórico e Artístico Nacional (IPHAN). É o primeiro processo de patrimonialização do estado do Rio Grande do Norte realizado pelo Programa Nacional do Patrimônio Imaterial (PNPI), após a implementação, em 2000, da política federal de salvaguarda do patrimônio cultural imaterial. O dossiê acompanhando o pedido recomenda a salvaguarda de bens associados à festa, como o bordado e as práticas alimentares consideradas tradicionais, tal qual o saber-fazer das "mestras de chouriço”. No entanto, se a festa continua mencionada no site do IPHAN, o patrimônio alimentar associado ao bem registrado não aparece mais nas publicações do órgão e nem foram realizadas ações de salvaguarda ao longo desses dez anos. As tradições culinárias locais foram esquecidas e a revalorização do saber-fazer das cozinheiras, em particular as que são de origem popular, não aconteceu. A ação patrimonial ficou no papel e não proporcionou uma emancipação econômica de fato para as populações detentoras destes saberes ${ }^{3}$. A questão chama atenção para a recepção das decisões tomadas pelas instâncias governamentais, o alcance limitado das políticas de cultura e a fragilidade das medidas de proteção dos saberes tradicionais. A implementação de políticas públicas voltadas para a cultura imaterial trouxe consigo problemas ligados à compreensão das noções utilizadas pelos agentes das práticas patrimoniais e às repercussões locais (ADELL, 2011; BORTOLOTTO, 2017; TIBÈRE, 2013). Os entraves institucionais e as contradições envolvendo a valorização dos sistemas alimentares tradicionais tomam proporções inéditas ao passo que o Brasil volta a constar no mapa da fome; que o atual governo libera quase 400 venenos proibidos no resto do mundo; 
que, numa canetada, extingue o Ministério da Cultura e nomeia um pastor à frente do Departamento do Patrimônio Imaterial do Instituto do Patrimônio Histórico e Artístico Nacional (IPHAN) - sabendo que parte dos bens registrados são ligados às religiões de matriz africana ${ }^{3}$. Num país onde o agronegócio manda na política, queima as florestas e invade territórios tradicionalmente ocupados, onde as igrejas pentecostais dividem o poder com o crime organizado nas favelas, como ficam os saberes populares?

Assim, a reflexão que trate dos embates envolvendo o patrimônio alimentar seridoense ultrapassa o legado histórico e cultural: numa região que se define pela referência a seu passado colonial (português) e que se perpetua no ato de comer, deve-se levar em conta aspectos da modernidade alimentar e as reviravoltas das políticas públicas. As pesquisas etnográficas sobre as comunidades quilombolas e o chouriço produzido na região do Seridó do Rio Grande do Norte foram realizadas no período de 2006 a 2018, no ensejo da festa de Sant'Ana, por ocasião do Inventário das Referências Culturais do Seridó, à luz das categorias de patrimônio (ADELL, 2011; BROMBERGER, 2014; PESTEIL, 2006), da cultura alimentar (CONTRERAS, 2011); POULAIN, 2013) e dos efeitos das políticas culturais (BORTOLOTTO, 2017; BROMBERGER, 2014; CUNHA, 2009) e mostram as ambiguidades e os descompassos entre a perspectiva institucional e os resultados da política cultural em nível local. Para entender as dimensões escondidas atrás dos processos de patrimonialização, serão avaliados os contextos socioeconômicos desiguais perpassados por fluxos migratórios e turísticos, e a instrumentalização da cultura por parte de agentes externos às comunidades detentoras dos conhecimentos e das práticas alimentares patrimonializadas (CONTRERAS, 2011; POULAIN, 2013; VILÁ; VÁZQUEZ-MEDINA, 2018).

\section{A DOÇARIA, UMA EXCEÇÃO SERIDOENSE?}

Tudo começou em dezembro de 2002, depois do sucesso da reportagem Brasil Total: Chouriçada - no Fantástico, em edição especial de Natal, que contou com a apresentação de Regina Cazé e de Titina Medeiros, atriz potiguar. A sequência é filmada na casa de Dona Angelita, em Carnaúba dos Dantas, com a encenação de um Natal sem Papai Noel. Um Brasil rural, autêntico, segundo a reportagem, com sotaque puxado, é revelado aos brasileiros em horário nobre ${ }^{4}$. Pouco tempo depois, Maria Isabel Dantas, sua filha, que orientou a equipe de filmagem, decidiu ingressar no doutorado e fazer uma etnografia do doce, mostrando a importância da prática na vida social e econômica da região ${ }^{5}$.

A ideia da reportagem era levar os espectadores para uma realidade pouco conhecida, inclusive para muitos nordestinos, que desconhecem o prato. De fato, o Seridó se projeta como um dos principais lugares de produção e consumo do chouriço, doce exótico preparado com farinha de mandioca, castanha de caju, rapadura, especiarias (canela, er- 
va-doce, cravo, pimenta-do-reino e gengibre), banha e sangue de porco. Apreciado por grande parte da população da região, é procurado pelos conhecedores que, ao degustá-lo, reencontram suas vivências no campo, a infância com a família numerosa e os gostos da terra natal. De sabor forte, devido às especiarias e à quantidade de açúcar, o doce é visto como tradicional, pois é fortemente associado à uma sociedade rural, à vida no sítio, ao trabalho coletivo e a um passado recente que ficou na lembrança dos seus moradores. Assim, estudando o chouriço, é possível visualizar a sociedade na sua totalidade, sua história, sua dinâmica, bem como perceber um estilo característico de vida e alimentação.

Inicialmente, é preciso situar o chouriço no universo gustativo, pois os doces ocupam um lugar importante no espaço alimentar do Seridó (POULAIN, 2013): consumidos como lanches, são oferecidos às visitas a qualquer hora do dia mas, em particular, para o café do final da tarde. É uma comida festiva e do cotidiano: o doce pertence ao universo social e cultural da região, sendo projetado como uma das principais marcas identitárias do Seridó ${ }^{6}$. Não é especificamente uma sobremesa, mas no caso de ser servido depois do almoço, os doces de fruta são preferencialmente consumidos com queijo de manteiga. É no café da tarde que se provam doces, pães e biscoitos, ocasião de reunir a família ou os amigos e "colocar os assuntos em dia" . Nos dias de festa, o café marca o fim das festividades e a despedida dos convidados. Da mesma forma, uma refeição leve e sem álcool é servida nas ocasiões que reúnem o grupo familiar ampliado (nascimento, batizado, aniversário, morte). São servidos licores e doces produzidos em casa ou comprados a artesãs conhecidas por suas habilidades. Assim, o doce é associado à ideia de consumo em família e, em particular, ao universo feminino e à infância.

Pery Lamartine, na sua crônica sobre a produção alimentícia na fazenda Timbaúba, em Serra Negra do Norte, onde passava as férias durante a infância, nos anos 1930, diferencia a produção destinada a ser comercializada daquela que era destinada ao consumo doméstico. Entre essas, destaca os doces e menciona o chouriço como uma produção regular:

Na produção de alimentos havia uma boa variedade para o uso em casa: cocadas, batata-doce, beijus, tapiocas, cuscuz, filhós, bolo de batata-doce, de mandioca, de milho, biscoitos de goma, sequilhos, chouriço de sangue de porco, doce seco com goiaba, de coco verde, linguiça, canjica de milho verde, pamonhas e vários outros produtos. Entretanto, só os queijos de manteiga representavam uma atividade lucrativa, embora produzidos de forma artesanal ${ }^{8}$.

Apesar de não se ter dados quantitativos sobre a importância dos doces para a produção artesanal no Seridó - pois é uma atividade muitas vezes informal -, há estudos pontuais que apontam para o papel dessa produção para a sobrevivência das famílias mais pobres, geralmente com mulheres negras vendendo seus doces para ter uma renda extra 
(SILVA, 2014; SANTOS, 2017; SANTOS 2020). Os doces são produzidos nos domicílios das famílias cujos membros terminam por se envolver na elaboração ou na comercialização dos produtos; assim, como é o caso de grande parte de nossos interlocutores, os filhos "ajudam" e terminam assumindo a produção familiar quando as mães se aposentam. As cozinhas são transformadas em espaço de trabalho e a casa é também um lugar de comercialização.

A doçaria designa qualquer preparação com açúcar, rapadura, melaço ou mel. São "doces caseiros" feitos com uma ou várias frutas (em caldas, geleias, cristalizados ou no "ponto" de doce). Chamados também de doces de tacho, os mais produzidos e consumidos são aqueles feitos com as frutas da época: goiaba, caju, coco, imbu' ${ }^{9}$ abacaxi, manga, mamão, jaca, banana etc. Há doces mais raros, como o de groselha, especialidade que Betânia Medeiros do Nascimento, em Jardim do Seridó, aprendeu com sua mãe; o "doce de pelo" ou gogoia, fruta da palma, é feito por Maria Salete Dantas, em Carnaúba dos Dantas. Há alguns doces mais elaborados e difíceis de serem encontrados, como o doce de batata com abacaxi ou os que recebem "temperos" (coco, cravo, canela, gengibre, castanha, erva doce, gergelim): o doce de espécie feito com gergelim serve para rechear o doce seco de Zélia Fernandes, em São João do Sabugi-RN, que, segundo nossos interlocutores, é cada dia mais difícil de ser encontra$\mathrm{do}^{10}$. Dona Zélia Maria de Lima (conhecida por Zélia Tum), em Acari, é uma das poucas doceiras a preparar o furrumbá, doce de coco com todos os temperos - ela aprendeu com sua avó que trabalhava na fazenda Talhado ${ }^{11}$. Em algumas preparações, o açúcar é o único ingrediente, como o alfenim, o puxa-puxa, o pirulito de açúcar ou o mel de rapadura, que serve de acompanhamento para comer um outro doce, como no caso do filhós ou é consumido com queijo quente. Outras preparações incluem, além do açúcar ou da rapadura, um outro ingrediente: o coco (cocada, o furrumbá), o leite (doce de leite, doce de leite com frutas), ovos (doce de ovos), batata ou farinha de mandioca crua e seca, como o doce seco. $\mathrm{Na}$ categoria de doces, incluem-se ainda os bolos (de ovos, de milho, de leite, de macaxeira, grude e preto ou pé de moleque), os biscoitos (de goma, de leite, de farinha de trigo, broas brancas e pretas), as comidas de milho (pamonha, canjica) e outros pratos que dependem das frutas da época ou que são preparados para ocasiões festivas: os filhós, bolinhos feitos à base de batata-doce são comidas de carnaval e agora são vendidos na festa de Sant’Ana de Caicó. O arroz-doce é geralmente preparado na Semana Santa. A imbuzada ou umbuzada, feita de leite, açúcar e umbus aferventados que, em Boa Vista, são coletados na serra vizinha, é servida fria. $\mathrm{O}$ chouriço parece ocupar um lugar específico nesse conjunto. É um doce de ocasião, festivo, pois é necessário que se reúnam muitas pessoas para trabalhar na sua preparação, tratar a carne, produzir alimentos que serão servidos durante o dia, fazer o doce e, no final do dia, organizar um jogo, uma rifa, cujo os benefícios vão para os donos da festa (DANTAS, 2008). 


\section{OS PRODUTOS ALIMENTARES E SEUS CIRCUITOS}

Para entender o papel e a importância simbólica da alimentação na sociedade potiguar, é necessário observar de perto a circulação dos produtos alimentares artesanais, como a carne de sol, os queijos, a manteiga, os biscoitos e os doces que são comprados no lugar de produção, levados para parentes como lembrança e que não obedecem a circuitos comerciais estabelecidos. O chouriço segue parcialmente essa lógica, pois não segue os padrões estabelecidos pela vigilância sanitária e a origem do doce é conhecida pelo comprador: o nome do produtor deve necessariamente ser conhecido.

Tradicionalmente, o lugar de produção do queijo era conhecido pelo ferro de marcar gado utilizado na fazenda. Presente desde o início da colonização, o ferro permitia identificar o proprietário do gado que era criado solto e era o brasão da família: cada filho recebia o ferro da família e acrescentava sua inicial (FARIA, 1984). Hoje, a marca do ferro tornou-se uma espécie de certificado de qualidade e de origem - o gado não é mais ferrado nas fazendas. É o selo do produtor, pessoa conhecida que pode ser identificada numa ampla rede de relações sociais. O sistema de comercialização que tem como base o interconhecimento e a confiança mútua reflete laços antigos, compondo uma economia informal e frágil, que se mantém ativa graças a laços de sociabilidade nos quais há uma circulação monetária limitada; vínculos tecidos entre famílias de produtores e de consumidores que se mantiveram ativos apesar do êxodo rural (MARQUES, 2015). Isso explica o valor afetivo das comidas de raiz que são naturalmente percebidas como patrimônios por nossos interlocutores, numa região essencialmente agrícola até meados dos anos 1980 e que sofreu historicamente com a fome e a seca (GONÇALVES, 2015).

\section{A FESTA DO PORCO}

As redes de sociabilidade que têm como base o parentesco e a vizinhança são reativadas no tempo da festa. Muito apreciado localmente, o chouriço é quase sempre preparado durante a matança do porco organizada para comemorar aniversários, casamentos, batizados, uma boa colheita, as festas de fim de ano, o padroeiro, momentos em que animais de criação são sacrificados. A família se reúne para celebrar a tradição, cozinhar e comer as comidas da terra. É uma festa que dura o dia inteiro e na qual o trabalho se mistura com a alegria de reencontrar parentes e celebrar a vida com muita fartura. Passar um dia em família no sítio significa voltar às suas raízes.

Todas as matanças de porco seguem o mesmo padrão. Foram acompanhadas, em particular, as festas do sítio Carnaúba de Baixo, nas proximidades da cidade de Carnaúba dos Dantas, em Jardim do Seridó e na comunidade quilombola da Boa Vista, em Parelhas ${ }^{12}$. O porco é abatido por um homem nas primeiras horas da manhã, geralmente o marchante 
que irá comercializar a carne, sem a presença das mulheres e das crianças. Após receber um golpe na cabeça, o animal é sangrado e recolhe-se o sangue para utilização imediata, para evitar que talhe. O porco é cortado e "tratado" pelos homens: a carne, incluindo o toucinho, é preparada para ser consumida durante a festa, vendida ou doada. Parte da carne será comida assada ou torrada, parte da banha é reservada ou utilizada na fabricação do chouriço. Serão feitas linguiças, e com a fissura completa, será preparado o picado ou sarapatel: todos os miúdos da parte do porco, o coração, o bofe, a língua, a garganta e o pulmão serão tratados, fervidos, cortados e temperados. O dono do porco fica apenas com o arrasto ${ }^{13}$, a cabeça, as vísceras, os mocotós e o sangue. Enfim, tudo é aproveitado.

Todo o grupo doméstico se envolve na preparação dos ingredientes que servirão para o doce: derreter a rapadura na água, peneirar a farinha, quebrar e ralar o coco, assar e quebrar a castanha, moer a pimenta e as especiarias, cortar a banha etc. A mestra ${ }^{14}$ coloca os ingredientes, mexe o doce, alimenta e controla o fogo com o auxílio dos filhos; todos conversam, comem, bebem, dançam, e no final, raspam o tacho. A sobremesa deve ser cozinhada no fogo à lenha por até nove horas para o sangue perder seu gosto e o perigo que é associado à sua ingestão isto é, a substância natural deve ser transformada em comida. O doce é colocado ainda quente em recipientes reutilizados - latas vazias de leite em pó, potes de margarina - e será rifado, doado ou, quando comercializado, será vendido nas feiras livres, de casa em casa, com o nome e a identificação da pessoa que o confeccionou.

Ao longo da festa, comidas são servidas de modo quase ininterrupto: o que falta na mesa do dia a dia é ofertado em abundância. Os anfitriões recebem marcas de reconhecimento, respeito e admiração por parte dos convidados que se sentiram em dívida, relançando assim o sistema de trocas que ocorre durante a criação do porco ${ }^{15}$. A efervescência coletiva reata os vínculos sociais, os laços de parentesco, as solidariedades com a vizinhança. A matança, os procedimentos culinários e a preparação do doce articulam laços de solidariedade numa espécie de comunhão com o animal e seu sangue, pois, ao consumir o porco, todos os presentes partilham da sua força vital, sua essência, e do sentimento de pertencimento a uma origem camponesa.

Assim, o chouriço não pode ser entendido fora do contexto em que é produzido e do grupo que promove a festa. Visto como um evento, o doce de sangue, quando consumido, é associado à excepcionalidade e às peculiaridades das redes de sociabilidades que são reforçadas na ocasião.

\section{O CHOURIÇO, UM DOCE DE EXCEÇÃO}

No Rio Grande do Norte, a produção e o consumo do chouriço é circunscrito ao Seridó. Associado à vida no sítio e à sociabilidade for- 
mada a partir das relações de parentesco e da vizinhança, a circulação do chouriço é limitada a um conjunto de pessoas que pertencem a uma rede de interconhecimento. Além disso, as transformações sociais tiveram como consequência uma urbanização crescente, tornando o chouriço um doce raro. No entanto, e apesar de aproximadamente 70 a $80 \%$ da população do Rio Grande do Norte morar nas zonas urbanas, observa-se que a criação de animais domésticos (porcos, carneiros e galinhas) em quintais continua sendo realizada por pessoas que estabeleceram residência nas periferias das cidades do interior.

Essencialmente feminina, a atividade artesanal - em particular fabricar doces - serve como complemento de renda, numa sociedade onde a circulação monetária é limitada (IICA, 2000, p. 189-190). São mulheres casadas ou viúvas, de origem social humilde, que criaram seus numerosos filhos sem o auxílio do genitor, e que se tornaram cozinheiras e doceiras. Mesmo morando na cidade, as famílias costumam manter um roçado onde criam animais destinados ao consumo próprio ou à venda, em caso de necessidade. O porco é alimentado com restos de comida (lavagem), frutas e legumes estragados, e, em alguns casos, ração. Nem sempre se tem "comer de porco" suficiente para engordar o animal. A alimentação é viabilizada por meio de "juntas" de restos de comida, preferencialmente coletadas nas casas dos parentes, amigos e vizinhos. Bares, restaurantes, pousadas, mercados, mercadinhos e feiras livres doam também produtos estragados que servem para alimentar os animais. Cotidianamente, a lavagem de porco é recolhida em baldes colocados em "carretinhas", puxadas por uma moto. O proprietário do animal tem obrigação de retribuir os que ajudaram a criar o porco, convidando-as no dia da festa ou oferecendo-lhes pedaços de carne e latas do doce. Nessa troca, há uma lógica econômica e uma força que obrigam o criador a retribuir na hora do abate do animal e da fabricação do chouriço.

Existem outras preparações culinárias feitas com o sangue de animais. Uma forma de cozinhar a galinha é à cabidela ou com molho pardo, adicionando o sangue no caldo de cozimento. Há também a possibilidade de acrescentar o sangue coalhado e cozido no final da preparação. O sangue dos caprinos e ovinos ${ }^{16}$ é usado na buchada. A buchada completa é um prato servido como tira-gosto ou refeição e cada vez mais associado a eventos festivos. O sangue, o fígado, o coração, pedaços de carne e/ou outras vísceras são lavados, fervidos, cortados, temperados e cozidos em bolsas - "saco" ou "buchadinha" - que medem cerca de $8 \mathrm{~cm}$ de diâmetro, confeccionadas com o estômago do animal. Há três técnicas para preparar as buchadas. Em alguns lugares, o recheio é composto de carne de criação cortadinha ou moída e temperada, podendo conter alguns pedaços de vísceras; em outros, o picado é preparado com fígado, coração, bofe e sangue, estes dois últimos ingredientes são opcionais. Há, ainda, uma especialidade feita à base de vísceras finas, misturadas ou não com essas partes. Normalmente as "buchadinhas" são 
cozidas conjuntamente com os mocotós, as tripas e a cabeça da criação, num caldo que serve para fazer o pirão. As partes da carne do animal que acompanham as buchadas formam a "panelada". A panelada é um prato composto pelo arrasto: os mocotós, a cabeça, as tripas, o fígado, os bofes, a garganta, o esôfago, a língua, os buchos e coração são temperados e cozidos com as buchadas.

Há uma série de cuidados relativos à ingestão de comidas feitas com o sangue de animais domésticos, as galinhas, os bodes, os carneiros e o porco. As proibições relativas ao chouriço nem sempre são respeitadas; apesar do perigo, arrisca-se pelo menos a provar, pois o doce é consumido em um momento especial, a festa. Assim, dado à excepcionalidade da ocasião, elementos considerados opostos podem ser misturados: o sangue, elemento natural por excelência, é temperado com alimentos processados e com gosto forte. O sabor do sangue desaparece com os temperos e o cozimento longo. No entanto, as pessoas adoentadas, as crianças pequenas, os idosos com uma saúde frágil ou as mulheres com pouca saúde ou menstruadas, os diabéticos são aconselhados a não comer o doce. As restrições se aplicam em particular a situações fisiológicas especiais, tais como cirurgia, doença infecciosa e inflamatória, menorreia. A carne de porco e o sangue são vistos como "carregados", podem provocar infecções, "ofendem" ou fazem mal à saúde. Assim, determinados alimentos teriam um efeito destruidor ao serem ingeridos, principalmente quando o organismo está fraco ou a pessoa tem o corpo aberto, sem defesa, incapaz de suportar o efeito de uma comida tão pesada e carregada.

Como em outros contextos etnográficos, as proibições relativas à carne de porco não estão relacionadas apenas ao caráter impuro do animal, à forma de criação e ao regime alimentar do animal, feito de comidas de natureza diversa (líquido ou sólido; plantas ou restos de comida; vegetal e animal etc.) (FABRE-VASSAS, 1994). A proximidade física do porco com os humanos explica em parte a atenção de que é objeto: na maioria das famílias, o porco é criado e tratado pelas mulheres, que são responsáveis pelo preparo das refeições, a horta e o cuidado dos animais de pequeno porte. É domesticado, apesar de não viver na casa, é confinado num chiqueiro nos arredores próximos das moradias e nos quintais. Come a mesma comida que as pessoas da casa, mesmo sendo os restos. O sangue do animal precisa também ser manipulado com cuidado: é recolhido, cozido lentamente - o fogo é contínuo, sua temperatura e o tempo de cozimento são controlados -, é misturado aos poucos com açúcar e especiarias que atenuam o gosto do sangue. De perigoso torna-se comestível, com poucas restrições. Ao se reunir ocasionalmente para realizar uma atividade altamente perigosa e sexualmente marcada, a família é ameaçada: o sangue e a carne de porco devem ser desumanizados e transformados numa comida que tem um valor de troca. $\mathrm{O}$ perigo envolvendo a transformação do animal doméstico em alimento 
comestível persiste após o cozimento, pois a carne e o doce continuam sendo pensados como perigosos. O tabu alimentar marca então a entrada do animal no reino da cultura (LÉVI-STRAUSS, 1964).

Nessa perspectiva, a patrimonialização do chouriço torna-se improvável, pois, por definição, o chouriço é associado a uma família e a um lugar de vida em particular. São indivíduos do mesmo sangue ou que pertencem a uma mesma localidade geográfica que preparam o doce, dividem as partes e consomem a carne do porco. Se a chouriçada é vivida como um momento excepcional, transformando-se num culto ao passado, é, acima de tudo, um marcador identitário, momento de grande efervescência social, quando um coletivo se reinventa, repete gestos dos ancestrais e garante a transmissão dos saberes.

\section{AS COMIDAS DA SANTA}

Devido às modificações da sociedade no seu conjunto, o doce de sangue tornou-se um bem raro e parece ser cada vez mais difícil serem organizadas festas familiares para matar o porco; hoje, verificamos que o doce é produzido para ser vendido como complemento da renda familiar, ainda que num perímetro limitado. Pode ser adquirido para ser levado de lembrança para um parente ou um amigo que não conseguiu vir para a festa. A festa de Sant’Ana de Caicó, que reúne um número importante de pessoas, é a ocasião do produtor escoar sua mercadoria. É a oportunidade para entender as percepções locais das produções alimentares e as contradições dos processos de patrimonialização.

O que Bromberger (2014, p. 150) chama de overdose patrimonial, criticando a crispação dos antropólogos nos registros do passado, não ocorre na região estudada, pelo contrário: as tradições festivas atraem cada vez mais uma população jovem indiferente às "coisas de antigamente", escapam das rotinas administrativas e fogem das mãos dos responsáveis encarregados da valorização da cultura que têm dificuldade em dar conta das rotinas burocráticas. Da mesma forma, a questão da apropriação das referências culturais por um grupo social específico e a reivindicação da autenticidade das expressões culturais tomou proporções não vislumbradas pelas agências e instituições encarregadas de encaminhar a documentação para efetivar os registros. Os desdobramentos dos processos de patrimonialização nem sempre foram previstos, pois não se preveem conflitos internos às comunidades: os detentores dos patrimônios - seria mais exato falar em "consumidores" - utilizam o reconhecimento conferido à autenticidade e origem dos produtos como arma política para reivindicar uma identidade, uma trajetória histórica, direitos coletivos ou, como vemos aqui, um estatuto social privilegiado. No final, as estratégias de distinção social associadas à ingestão de comidas destoam da filosofia da Unesco que incentiva a promoção da diversidade cultural e prioriza o reconhecimento dos patrimônios invisibilizados (BORTOLOTTO, 2017; CUNHA, 2009). Em Caicó, a 
questão se coloca da seguinte forma: o consumo das comidas da terra corresponde a uma busca de autenticidade por parte de pessoas que migraram, mas que continuam se definindo como seridoenses e afirmam sua origem participando de festins gastronômicos. São moradores das grandes cidades nordestinas ou do Sudeste do país que adquiriram um estatuto social elevado e que voltam para se confraternizar e reencontrar familiares ${ }^{17}$. Deve ser a razão pela qual constata-se uma certa indiferença em relação ao reconhecimento da festa pelo Estado brasileiro. $\mathrm{O}$ que interessa aos filhos da terra é a possibilidade de visitar a santa, rever os parentes e reviver a história da cidade. Mesmo depois do reconhecimento da festa de Sant'Ana pelo IPHAN, em 2010, ficou apenas a Igreja a lembrar que a celebração se tornou patrimônio nacional, numa indiferença quase generalizada. Organizada nos moldes de uma festa de padroeiro durante a última semana de julho, são dez dias em que as procissões, as missas - retransmitidas via youtube para quem não puder participar -, as bênçãos, as quermesses, os shows das bandas da moda, as feiras e os eventos festivos se sucedem num ritmo frenético, reunindo mais de 100.000 participantes cada ano. É a maior festa de padroeiro do estado do Rio Grande do Norte (MORAIS; DANTAS, 2006). Os filhos de Sant'Ana, devotos e foliões, se reúnem para a ocasião, reinventam uma identidade sertaneja, inspirando-se num repertório festivo misturando as referências culturais. Os "filhos ausentes" retornam à terra de Sant'Ana para reencontrar os familiares, num grande banquete que dura o tempo da festa e convidam seus amigos para celebrar Caicó. As pessoas públicas e os políticos do estado fazem questão de participar, pois é um evento que tomou uma dimensão regional. A feirinha é o ápice da festa, organizada na última quinta-feira ao redor da Catedral, no centro histórico da cidade, próximo ao lugar de sua fundação. As "famílias tradicionais" são reunidas - são as famílias mais ricas -, que mantêm a casa dos ancestrais "na rua" (a cidade), mesmo se migraram para as metrópoles há gerações. É a ocasião de celebrar um passado e uma identidade que se expressam numa sociabilidade festiva e no reencontro das famílias extensas. Para quem fica nas cozinhas, a festa muda de sentido: é a ocasião de ganhar um dinheiro suado. A encenação da cultura da opulência e do exagero gastronômico (e alcoólico) pode ser observada nos espaços públicos, especialmente no dia da feirinha de Sant'Ana. Em vários momentos, a festa profana ultrapassa a religiosa, criando atritos com as autoridades da igreja, que repreendem os abusos durante os cultos.

Segundo Pesteil (2006, p. 15), a "inversão dos estigmas e de uma vontade de salvaguardar saberes-fazeres, incita a ver no fato alimentar ao mesmo tempo um pilar do desenvolvimento de um turismo de descoberta e de uma política de valorização e de proteção das produções locais". Ao ingerir as comidas de raiz, modo de chamar os pratos considerados tradicionais, são lembradas as histórias das famílias abastadas 
que afirmam uma origem e uma identidade territorial, tendo como fundamento a história, a paisagem marcada pelas secas, o sistema socioeconômico baseado na criação bovina e em escolhas culturais ligadas ao universo dos coronéis.

\section{A FEIRINHA}

No dia da feirinha, organizada na última quinta-feira da festa, os "filhos de Sant'Ana" se fazem presentes, disputando as mesas em torno da Igreja. A praça principal da cidade é tomada pelos convivas. É o ápice da festa e representa um momento de intensa comercialização de alimentos, em que todos os fiéis comungam, consumindo os pratos de Sant'Ana.

Voluntários participantes da comissão de organização da festa trabalham na preparação, venda e distribuição das refeições: os fiéis são sentados em fileiras, nas mesas montadas no meio da praça, ao lado da matriz. Pratos de "comida típica" são vendidos em benefício da Igreja: arroz de leite, paçoca, feijão-verde, carneiro, buchada, xerém, picado que é também chamado de sarapatel -, vatapá de camarão, churrasquinho, queijos, doces e bolos. As bebidas alcoólicas, proibidas nos outros dias da festa, são vendidas ou trazidas pelos farristas, que se reúnem nas mesas, em uma arquitetura pensada para se ter uma visão ampla da festa e ser visto pelos demais; percebe-se a hierarquia social, em que os mais ricos escolhem os lugares mais próximos da igreja. Em particular, os homens bebem exageradamente, de manhã até de noite, antes das festas noturnas (shows), que terminam de madrugada. As noitadas se prolongam nos botecos e alguns oferecem cafés da manhã regionais, com bastante "sustança" - são, com algumas variantes, os mesmos pratos servidos no almoço. Após tirar a ressaca e descansar um pouco, é preciso recomeçar, algumas horas depois.

Como na matança do porco, versão rural e familiar que segue os padrões festivos locais, onde há muita gente, barulho, comida e bebida em exagero, a festa de Sant'Ana apresenta um verdadeiro potlatch, do qual os menos ricos participam de maneira marginal, como espectadores ou trabalhadores, servindo os convivas. As famílias ricas, instaladas no centro da cidade, nas proximidades das casas de parentes, mostram com ostentação seu bem-estar e seu status social; oferecem generosamente comida e hospedagem aos convidados, que devem aceitar sob pena de ferir o anfitrião. A praça torna-se uma extensão da casa - os lugares são reservados - e se tem a impressão de participar de uma grande comunhão. As comidas consumidas são as de uma sociedade rural, produtora dos seus alimentos, organizada em torno de uma figura feminina: a santa, que é, antes de tudo, uma mãe protetora, uma avó. Celebração da maternidade, da fé católica, das tradições familiares, a festa é uma cena na qual os participantes mostram seu sucesso econômico, em particular com seus carros de luxo, ostentando roupas de marca, joias e mesas 
fartas, participando dos leilões organizados pela igreja e gastando sem contar para festejar.

Ao ressaltar a identidade local, o evento favorece um endoturismo voltado para o consumo alimentar e a venda de produtos locais, associados a formas de sociabilidades que são vistas como a expressão genuína da cultura. Num fenômeno parecido àquele observado na Córsega por Pesteil (2006, p. 15), a reapropriação cultural se acompanha de uma inversão dos estigmas e se traduz por uma valorização do local que serve também para o turismo; aqui limitado à região e aos tradicionais lugares de migração, o Sudeste e o Centro-Oeste. As famílias pobres, os moradores dos sítios, trabalhadores agrícolas, vaqueiros, empregados domésticos, não sentam nas mesmas mesas - muitos deles são negros, descendentes dos escravizados. Eles participam discretamente da festa, vendendo seus produtos, atrás das panelas, servindo os comensais.

\section{ALIMENTOS, FOLCLORE E TURISMO}

As tradições alimentares oferecem uma tradução concreta de uma região portadora de história e de cultura, é essa ideia que encontramos na palavra francesa terroir. Os "produtos da terra" religam automaticamente o indivíduo a saberes compartilhados, a uma trajetória familiar e a um lugar de origem (PESTEIL, 2006). ${ }^{18}$ De certa forma, as preparações culinárias correspondem à ideia naturalizada de patrimônio, e são sinônimos de arcaísmo e folclore: uma tradição genuína transmitida oralmente de mãe para filha, enraizada num território de exceção, que teria sobrevivido aos séculos. A cultura alimentar é formada por um "conjunto de representações, de crenças, conhecimentos e de práticas herdadas e/ou aprendidas que estão associadas à alimentação e que são compartilhadas pelos indivíduos de uma cultura dada ou de um grupo social determinado dentro de uma cultura" (CONTRERAS; GRACIA, 2005, p. 37). Na verdade, as tradições culinárias retratam as fraturas sociais e raciais que têm origem na sociedade colonial.

No Seridó potiguar, a comida da terra é apresentada como um dos itens na reivindicação de uma tradição histórica e de uma identidade regional, tendo como referência a sociedade colonial que se estruturou no século XVII. É como se fosse possível viajar pela história ao degustar um "prato típico": no imaginário regional, os fundamentos da cultura do sertão, como a doçaria, seriam provenientes de Portugal e teriam sido conservados quase intactos desde o século XVII! Não é de se estranhar que este seja o caso do chouriço: o fundador de Acari, Caetano Dantas Correia, teria oferecido carne de porco e o doce a frades inquisidores para comprovar que não era judeu. Na verdade, no doce que o cristão-novo comeu, não havia sangue mas gergelim; o doce de espécie teria nascido na ocasião (DANTAS, 2008, p. 41-47) ${ }^{19}$. Nesse sentido, a sobremesa ilustra os embates presentes na fundação da cidade e da região. Reflete em parte a ideia de que o alimento é associado ao processo civilizador, hipóteses reiteradas na literatura sobre a história do Nordeste. 
Assim, o autor da "História da alimentação no Brasil", Luís da Câmara Cascudo (2011), propõe uma leitura da sociedade brasileira a partir das dietas indígenas, africanas e portuguesas, mostrando as trocas culturais operadas nas preparações alimentares (Cavignac; Oliveira, 2012). O folclorista potiguar atribui ainda o sucesso da conquista do sertão a uma comida, a paçoca, carne de sol pilada com farinha, de fácil conservação e transporte. Esse prato genuinamente sertanejo, associado à rapadura, teria sido o sustento dos desbravadores nas guerras contra os índios (CASCUDO, 2011, p. 741-752). Mesmo se precisamos desconfiar dessa leitura simplificada da história, esta revela a importância da alimentação na representação do passado, destacando a questão colonial na associação da carne seca, da farinha de mandioca e do açúcar bruto.

Em outro nível, a valorização dos produtos do sertão que observamos nas capitais turísticas do Nordeste é fruto de uma reapropriação indevida dos marcadores identitários dos grupos marginalizados ${ }^{20}$. Pode ser analisada como uma das consequências da urbanização brutal da sociedade brasileira, com a migração de populações rurais para as cidades. Por sua vez, o turismo impulsionou um movimento de patrimonialização fora dos padrões da UNESCO, criando elementos icônicos visando responder a uma demanda de cultura autêntica. Os investimentos turísticos e de infraestrutura implementados nessa última década colocaram a região Nordeste como um dos primeiros destinos de turismo nacional entre 2006 e 2013. A partir daí, foram organizadas feiras de produtos artesanais, festivais gastronômicos e roteiros temáticos para incentivar e diversificar o turismo. Concomitantemente, houve um aumento das marcas da cultura rústica nas cidades, em particular com os restaurantes destinados a um turismo de massa, oriundo das regiões Sul e Sudeste do país, onde há um maior poder aquisitivo.

Ignorando os protocolos institucionais e as instâncias que regulam os processos oficiais de patrimonialização, vereadores, deputados e outras autoridades políticas decidem o que será reconhecido. Apresentam projetos de lei e proclamam especialidades culinárias patrimônios, sem sabermos as razões para uma tal decisão. Assim, em 2014, na época da Copa do Mundo, circulou um abaixo-assinado na internet para que a ginga com tapioca do mercado da praia da Redinha, em Natal, fosse reconhecida como patrimônio. ${ }^{21}$ Foi decretada patrimônio da cidade do Natal em 2016, após ter sido objeto de reportagem numa revista nacional de grande circulação, a Veja; dois anos depois, foi sancionada patrimônio do estado do Rio Grande do Norte. Em 2017, sob pressão política feita por alguns produtores, foi criada uma lei estadual que protege a fabricação artesanal dos queijos de manteiga e de coalho e da manteiga de garrafa. Em 2019, foi a vez do caldo de cana de Ceará-Mirim, do pastel de Tangará, da carne de sol e do queijo de coalho de Caicó, que foram indicados pela Assembleia Legislativa do Rio Grande do Norte. Em 2021, a Lei 10.903 declara o grude de Extremoz, uma preparação 
com goma de mandioca, sal e coco, patrimônio estadual; já constava na Arca do Gosto do Slow Food desde 2017. Esses procedimentos visam dar destaque a elementos que fazem referência a um complexo cultural de uma localidade ou uma região, e servem aos interesses de grupos ligados a setores do turismo e da alimentação, levando a uma folclorização turística (BROMBERGER, 2014). O reconhecimento via Assembleia Legislativa, mesmo que não tenha consequências práticas para os grupos detentores desses saberes, corresponde à ideia de autenticidade da produção cultural: ao ingerir os pratos típicos, o turista pode ter um acesso direto a toda história e cultura que envolvem as preparações. No litoral, as plantações de cana de açúcar (cachaça), as atividades de subsistência (pesca e cultura da mandioca), no sertão, as fazendas de gado (queijos e carne de sol). Em todos os casos, através do alimento, é a história colonial que é valorizada e não o conhecimento e o trabalho das cozinheiras. Para o doce feito de sangue, produzido artesanalmente por pequenos agricultores, a patrimonialização parece difícil, sendo um alimento raro, exótico, facilmente perecível e quase sempre comercializado pelas redes de interconhecimento.

Enfim, o surgimento recente dos produtos da terra de fabricação semiartesanal nos centros urbanos, nas lojas de produtos do sertão, nos supermercados que investem nas marcas locais e nos lugares turísticos, se acompanha de uma mudança radical do sistema alimentar das famílias pobres, com a introdução maciça de produtos provenientes da indústria alimentar. No Nordeste, onde encontram-se mais da metade dos beneficiários da bolsa família, que foi implementada há mais de dez anos, as políticas sociais tiveram um impacto direto no consumo alimentar, possibilitando o acesso a um volume maior de produtos para os mais pobres. No entanto, isto não se traduziu necessariamente em uma dieta mais saudável, pois os novos consumidores mantêm uma alimentação rica em gordura e açúcar (IBASE, 2008; IPEA, 2016, p. 31). Se há mais proteínas do que no passado, essas provêm da indústria alimentar, tornando a dieta menos variada; os produtos frescos, cultivados nas hortas, nas zonas rurais, desaparecem dos cardápios, em particular durante os períodos de seca. Os supermercados ou pequenos comércios de proximidade que se desenvolveram durante esses últimos anos em toda a região vendem poucos produtos frescos; encontram-se mais frequentemente refrigerantes, enlatados e produtos manufaturados. Assim, o sertão exporta a imagem de uma sociedade agropastoril que ficou no passado.

Os produtos da terra, mais saudáveis, agora valorizados e patrimonializados, passam a ser controlados pelas agências sanitárias, devem se adequar às normas dietéticas e às modas gastronômicas. As comidas de raiz, antes consumidas diariamente pelos trabalhadores do campo, destinadas agora aos citadinos, tornam-se comidas de festa. 


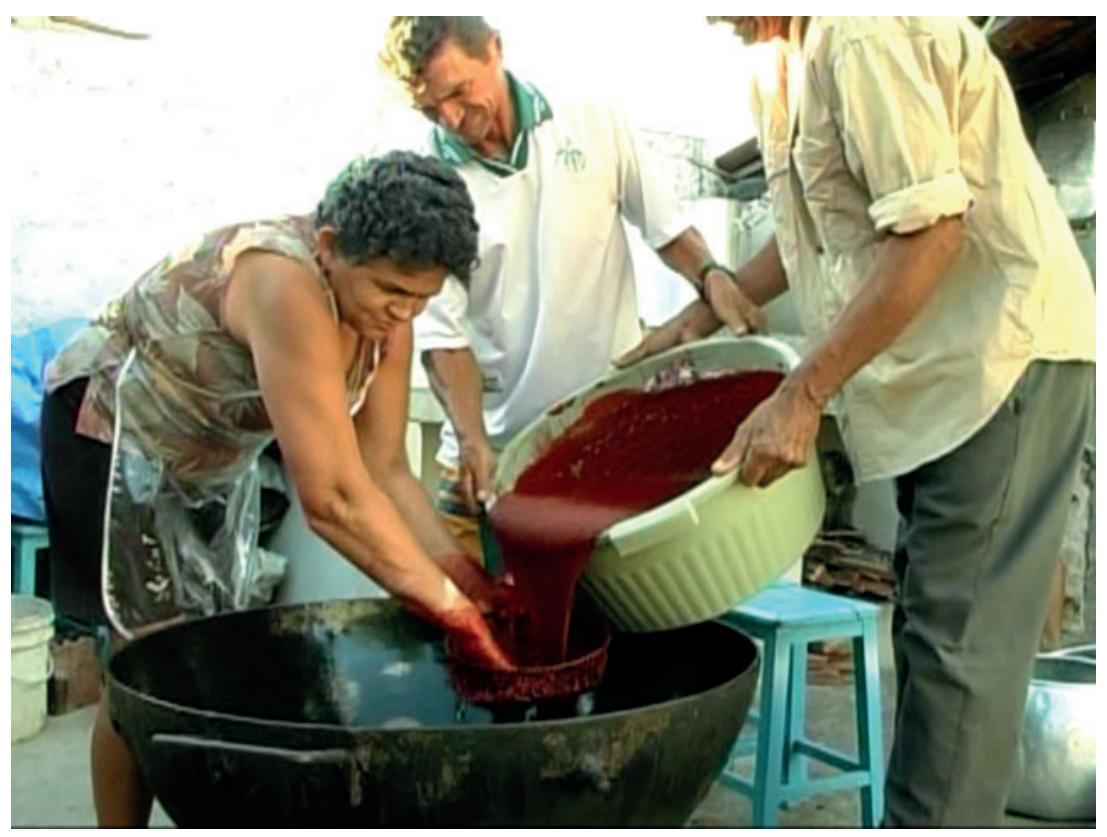

Dona Inácia coloca o sangue no chouriço. Foto: Isabel Dantas, 2008

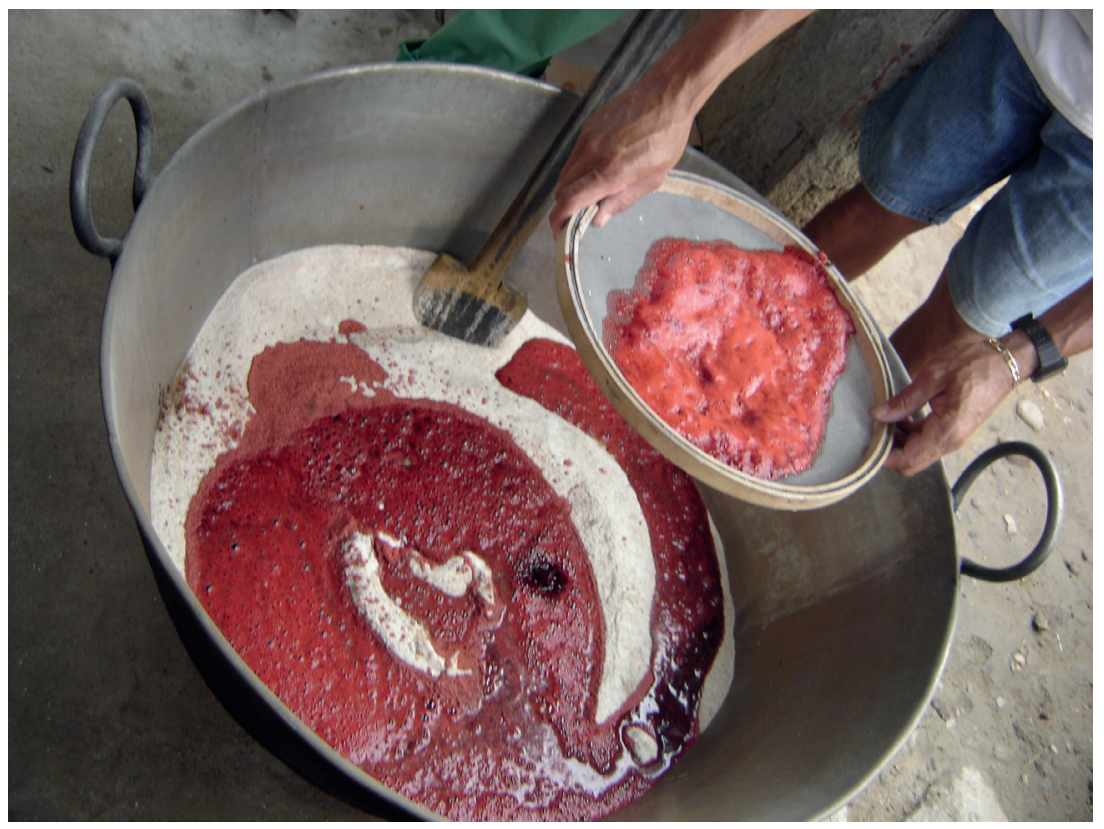

Sangue na farinha. Foto: Isabel Dantas, 2008

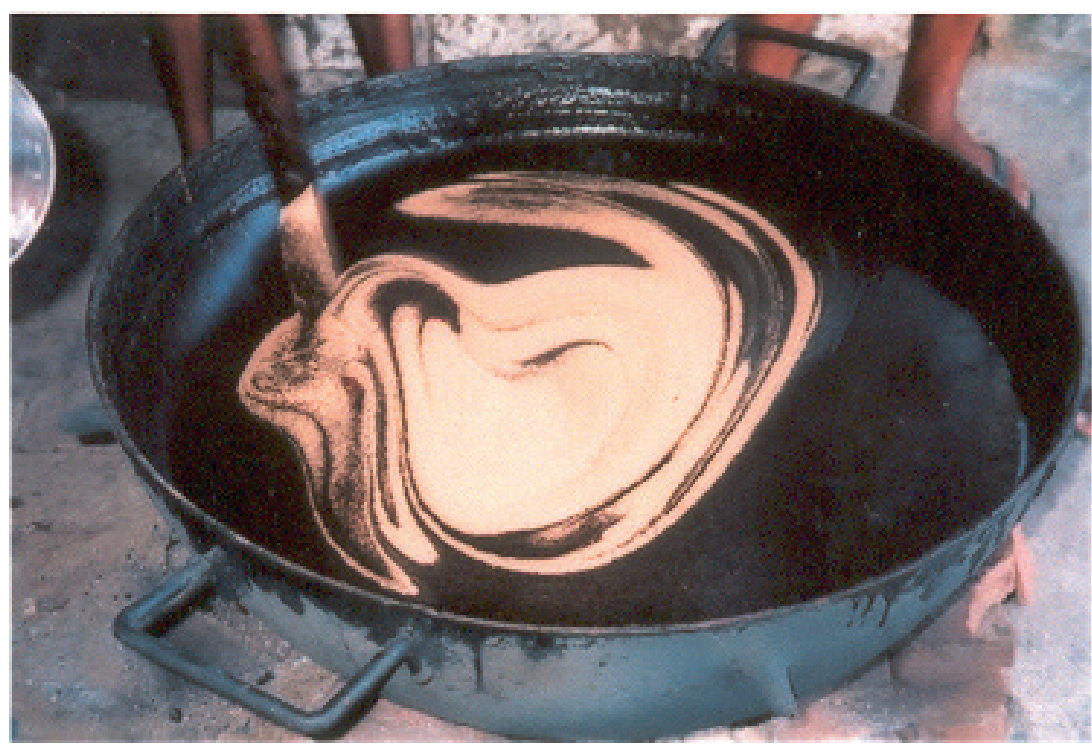

ก

Mexendo o chouriço em Carnaúba dos Dantas. Foto: Isabel Dantas, 2008 


\section{PATRIMÔNIOS INTANGÍVEIS}

Deixando para trás aspectos folclorizantes e deslocando o protagonismo político para as questões étnicas, o Ministério da Cultura publicou o Decreto $\mathrm{n}^{\circ} 3.555$ de 2000, visando se adaptar às orientações da UNESCO (LIMA FILHO, 2009). O cantor Gilberto Gil, à frente do Ministério da Cultura, entre 2003 e 2008, iniciou os processos de patrimonialização e os inventários nacionais de referências culturais (INRC). ${ }^{22}$

Interessante notar que, no Brasil, entre as ações que prefiguram a mudança na concepção das políticas culturais para registrar o patrimônio intangível, houve uma primeira ação reconhecendo a importância da cultura afro-brasileira: o tombamento do terreiro da Casa Branca e do quilombo dos Palmares em 1986, que iniciaram o debate sobre o lugar da escravidão na história do país. Encabeçadas por ativistas e antropólogos, essas iniciativas irão se traduzir, na nova Constituição de 1988, em obrigatoriedade do tombamento dos documentos e dos monumentos das comunidades de remanescentes de quilombos (VELHO, 2006) ${ }^{23}$. Quinze anos depois, as medidas constitucionais serão efetivadas e irão provocar uma revolução institucional no órgão responsável, o IPHAN, e na sociedade como um todo, com outras iniciativas na Educação e na regularização dos territórios.

O reconhecimento dos bens culturais de natureza imaterial parece ter sido um caminho mais fácil para incluir o legado africano na narrativa nacional, assunto delicado que toca feridas abertas da sociedade brasileira. Para encurtar a história, e prenunciando o golpe de 2016, a educação, o mundo artístico, as políticas de incentivo à cultura foram demonizadas, confundidas com as pautas de esquerda e os governos do Partido dos Trabalhadores. No entanto, se, entre os anos 2003 e 2016, foram impulsionadas ações de valorização das tradições populares, em particular a partir das reivindicações do movimento negro, o Rio Grande do Norte escapou da onda de fascinação histórica que caracteriza o surgimento dos processos de patrimonialização (ADELL, 2011, p. 09-11; BROMBERGER, 2014). As expressões culturais e o passado não são valorizados: houve poucas ações realizadas, e essas ou não tiveram quase nenhuma repercussão ou não seguiram os protocolos traçados pelas agências de cultura (CAVIGNAC et al., 2010). Alguns atribuem o descaso a uma falta de sensibilidade patrimonial que se observa também na destruição dos sítios arqueológicos e do patrimônio histórico das cidades brasileiras.

Estranhamente, não há nenhum registro de conhecimentos associados às preparações culinárias brasileiras entre os bens inscritos na lista representativa do patrimônio mundial da UNESCO. ${ }^{24}$ Nacionalmente, encontramos várias menções a saberes ligados a gêneros alimentícios; entre eles, o das mestras de chouriço na festa de Sant'Ana de Caicó. ${ }^{25}$ Por trás dos dossiês apresentados para a inscrição como Patrimônio Cultural Imaterial (PCI), aparecem situações atípicas, que mostram uma 
associação entre um patrimônio culinário e uma tradição sedimentada (ADELL, 2011, p. 18). Assim, enquanto o antropólogo procura conhecimentos tradicionais, o político, o jornalista ou o turista enxergam o produto "típico". É o caso das produções artesanais e das preparações culinárias que se inserem num mercado cada vez mais procurado, com o apelo ao local, o tradicional e o saudável. O reconhecimento fortalece redes locais de produção e comercialização, fugindo das rotinas patrimoniais e os bens adquirem um valor suplementar ao receber este selo de autenticidade (TIBÈRE, 2013). É o que acontece com o queijo e a cachaça, em todo Nordeste, que escapam do controle do Estado. Assim, é preciso incorporar à reflexão os produtos e as estratégias desenvolvidas para o turismo, observando a seleção, a ressemantização e a valorização de elementos de uma cultura local feitas por agentes externos às comunidades detentoras dos saberes. ${ }^{26}$

Em 2004, foi implementado o Roteiro Seridó pelo Serviço Brasileiro de Apoio às Micro e Pequenas Empresas - Sebrae-RN e a Secretaria de Turismo do Estado, impulsionado pelo programa de regionalização do turismo promovido pelo Ministério do Turismo; mas não teve o sucesso esperado e poucos projetos estão ativos. Em 2006, foi organizado o primeiro Festival Saboreando pela mesma agência, com premiação de pratos e de produtos locais, visando promover a culinária local e incentivar a produção de queijos artesanais. Aproveitando o frenesi que a comida provoca, com os programas de televisão e o atrativo para os turistas, desde os anos 2005 organizam-se feiras de produtos locais e festivais gastronômicos nas cidades turísticas: Pipa, São Miguel do Gostoso, Martins, Portalegre, Gameleiras etc. Caicó, que se autodeclara capital regional da gastronomia, pela qualidade dos seus produtos, tem vários restaurantes que inovam em termos culinários, mas todos oferecem uma comida regional; além da feira que ocorre anualmente durante a festa de Sant’Ana, desde 2003, ocorreram várias edições do Festival de Carnes e Queijos, organizado por membros de uma associação de comerciantes. Em 2015, foi realizada a primeira edição do Festival Gastronômico e, em 2019, ocorreu o encontro de 70 doceiras da região, oriundas de 11 municípios do Seridó. Esses eventos mostram a importância da produção familiar para a economia local e o gosto que os seridoenses têm para seus produtos de erroir $^{27}$. A municipalidade ou atores da iniciativa privada organizam os eventos com o auxílio de patrocinadores, mas sem a participação do IPHAN.

O curioso trâmite do processo mostra as hesitações burocráticas do registro. Se o pedido de registro da festa de Sant’Ana de Caicó como bem imaterial foi proposto pela Diocese de Caicó e pela Paróquia de Sant'Ana em 2010, junto com as assinaturas dos fiéis, no entanto, o dossiê já tinha sido constituído em 2008 e encaminhado pela Superintendência do IPHAN no Rio Grande do Norte para Brasília. Houve uma solicitação de complementação em 2009, como parte do Inventário das 
Referências Culturais do Seridó, que era o projeto inicial da instituição. Como justificativa:

A região do Seridó é lugar de destaque no cenário do sertão do Rio Grande do Norte, por sua história original, sua religiosidade vivida no cotidiano, sua tradição culinária e festiva, motivos de orgulho dos filhos da terra de Sant'Ana. Se, localmente, essa particularidade é reconhecida e valorizada, verificamos que não existiam ainda ações dos órgãos governamentais para a promoção e a valorização da cultura local. ${ }^{28}$

O texto que foi produzido para o registro da festa de Caicó não esclarece por que o chouriço foi escolhido, nem como se associa à maior festa católica do estado: nem o que identifica uma tradição culinária da família ampliada, oriunda de um mundo rural marcado pela miséria e pelas privações, à festa da elite regional, hoje urbanizada, que celebra na ocasião suas origens. É fato que a comida ocupa um lugar de destaque na sociedade potiguar, em especial nas festas comunitárias, mas por que ter escolhido o doce de sangue? Qual fundamentação foi avançada? Partiu de uma demanda de um grupo de produtores? Teria sido escolhido pelo seu caráter exótico? De qualquer forma, se poucos têm conhecimento do registro da festa, quase ninguém soube das recomendações de salvaguarda dos saberes das cozinheiras e nada foi feito em quase dez anos! Nesse caso, podemos falar de patrimônio invisível pois, de fato, as instâncias institucionais conseguiram apenas apontar a importância do saber tradicional, sem implementar ações efetivas de salvaguarda. ${ }^{29}$

Entre outras propostas de ações, recomenda-se que:

Com o intuito de salvaguardar os ofícios de bordadeira e mestra de chouriço e dos modos de fazer bordado e doce de chouriço, propõe-se ações que incentivem e garantam a transmissão dos saberes para as gerações mais novas, como a realização de oficinas, mostras e concursos culturais, bem como a documentação textual e visual destes ofícios (IPHAN, 2011, p. 114).

Assim, o esquecimento dos saberes associados ao bem registrado os das cozinheiras - mostra que a instituição contribui, ao final, para a reprodução das fraturas sociais.

Além disso, a comida aparece como elemento de referência na constituição identitária, sendo quase consubstancial a esta, pois participa do sistema histórico, cultural e social do grupo, e, ao mesmo tempo, pertence à esfera do íntimo, da família, do segredo, da emoção (ADELL, 2011, p. 19; FISCHLER, 1996; MINTZ, 2001). Os conhecimentos envolvendo as plantas e os produtos alimentares revelam ainda a estrutura social, as trocas, as solidariedades e os códigos simbólicos que são traduzidos em hábitos e padrões alimentares socialmente incorporados (LÉVI-STRAUSS, 1964; WOORTMANN, 2013). São as expressões de uma memória sensorial que pertence às esferas menos conscientes das trajetórias familiares. $\mathrm{O}$ chouriço seria então um alimento identitário que remete a uma história coletiva, uma forma de vida e um modo de 
produção - a do sítio camponês, caracterizado por um sistema de espaços diversificados, complementares e articulados entre si (WOORTMANN, 1995). Ao associar um doce feito com o sangue e a banha de porco a uma festa católica que continua veiculando uma versão colonial da história, mesmo sendo uma proposta louvável por parte do IPHAN para valorizar um saber popular, ocorre uma descontextualização das referências culturais e um apagamento das diferenças sociais entre os grupos, o que leva a uma folclorização do chouriço.

Por sua vez, os antigos locais de produção (sítios, fazendas, usinas de algodão), as festas (padroeiro, vaquejada, forró, carnaval) ou as expressões culturais de caráter étnico (Festa do Rosário, Dia da Consciência Negra), são ocasiões que atraem uma população urbana à procura das suas origens rurais e de uma cultura "autêntica". Assim, no Seridó como alhures, os saberes e as tradições culinárias são de domínio feminino (HERTZ apud ADELL, 2011, p. 223-238). A aquisição e a transmissão desses conhecimentos se dão na esfera doméstica, entre as mulheres, as patroas e as empregadas. Nas "casas de família", onde as cozinheiras negras trabalham como empregadas, as comidas são feitas para o consumo diário e para as festas familiares que reúnem a parentela extensa. Algumas dessas cozinheiras são reconhecidas pelas suas habilidades culinárias e são contratadas para fazer as refeições e os doces consumidos nas ocasiões festivas. Ao cozinhar, as "mestras" expressam sua história e imprimem sua marca, trazendo o conhecimento e as vivências das suas ancestrais. Escutando as histórias de vida das cozinheiras negras, temos acesso às suas formas de sobrevivência e estratégias de resistência à opressã ${ }^{30}$. Mesmo com as conquistas acumuladas, a trajetória profissional das mulheres segue de perto as das suas mães e avós que foram escravizadas. Assim, na Boa Vista dos Negros, as moças começam a serem babás, empregadas domésticas, algumas conseguem se profissionalizar, com uma formação técnica (auxiliar de enfermagem, costureira, merendeira, cozinheira etc.) ou tornam-se autônomas, à frente de uma pequena empresa na cidade de Parelhas ou na comunidade quilombola. A fragilidade econômica, no entanto, marca essas trajetórias.

Os elementos culturais encenados pelos moradores do Seridó como sendo tradicionais correspondem a uma retórica passadista. Além de reproduzir fraturas sociais, as práticas e os saberes culinários são reflexos de uma dominação colonial ainda vigente (BOURDIEU, 1979). Para que os "alimentos da terra" sejam consumidos em meio urbano, eles devem ser transformados em produtos gourmets e se tornar uma bandeira da identidade cultural regional. Aqui os conflitos não aparecem, o campo é folclorizado e é associado a um passado exótico: os pratos típicos não seriam a materialização da versão colonial da história e a prova da existência das estruturas de dominação em vigor até hoje? Entende-se então por que as questões raciais, as desigualdades e os conflitos territoriais continuam silenciados. 
No caso das cozinheiras negras, a arte culinária desenvolvida nos fogões à lenha das antigas fazendas do Seridó revela uma resistência silenciosa; a memória corporal, as técnicas, os gostos, carregam uma herança pouco valorizada.

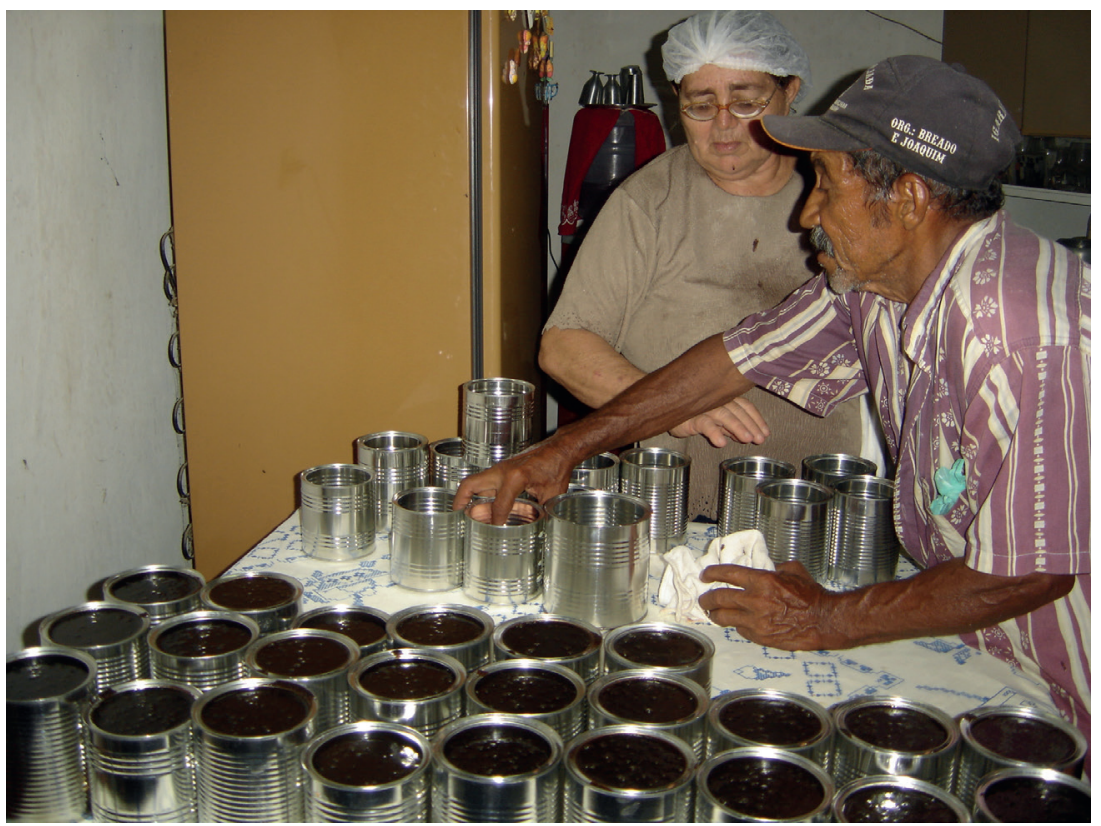

Seu Chico e Dona Luzia enchendo lata. Foto: Isabel Dantas, 2008

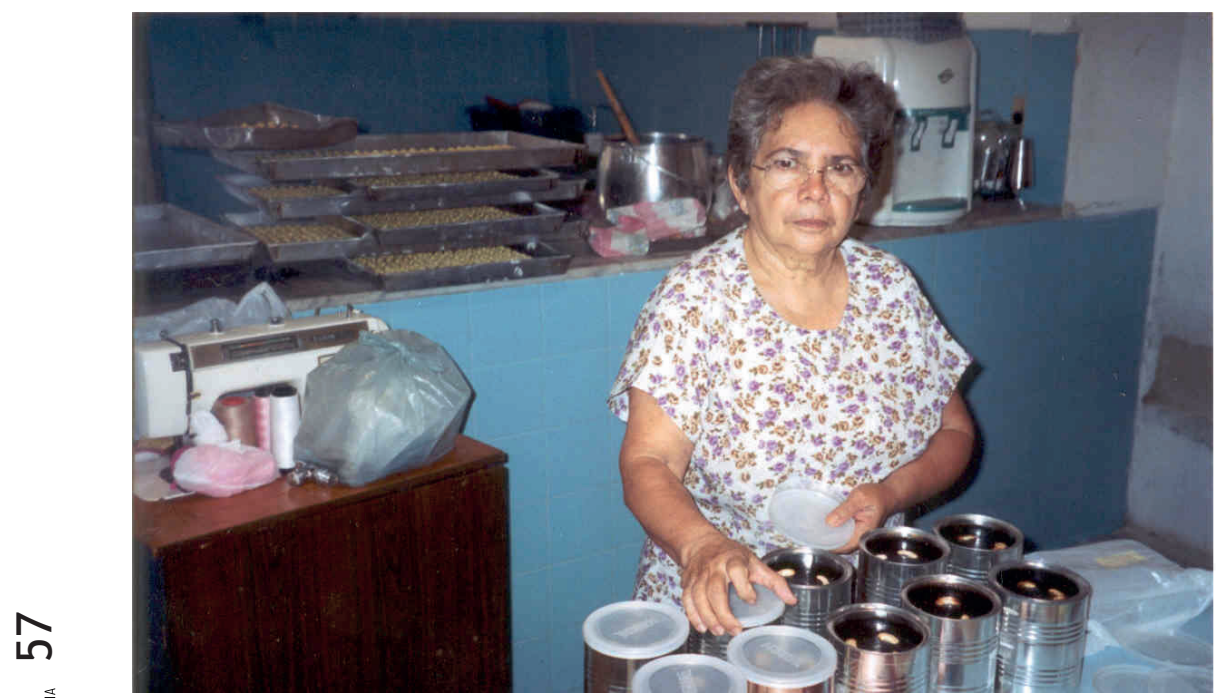

Chouriço em Carnaúba dos Dantas. Foto: Isabel Dantas, 2008

\section{UM PATRIMÔNIO IMPOSSÍVEL}

As pesquisas sobre o lugar reservado à alimentação nas dinâmicas sociais contemporâneas nos levam a entender as relações entre os grupos, as escolhas culturais e as transformações de uma população que se urbanizou, mas que continua se identificando com as referências culturais do mundo rural. 
Assim, o doce de sangue informa sobre as contradições de uma sociedade profundamente desigual, que tem como linguagem a comida: abundante, rica em carne e em gorduras animais com alto valor comercial (queijo, leite, nata), é oferecida generosamente nas ocasiões festivas, numa encenação da história feita por uma elite que se representa como branca (portuguesa). Dificilmente os mais pobres têm acesso à carne vermelha, reservada aos dias de festa ou à comercialização: tiveram que inventar uma gastronomia a partir das partes menos nobres dos animais e entre elas, uma substância que repulsa e fascina, o sangue, que é transformado em chouriço ${ }^{31}$. Ao celebrar o patrimônio do Seridó na festa de Caicó, a sociedade atualiza padrões de comportamento autoritários diretamente herdados da colonização que invisibilizam a história daqueles que produzem os alimentos, preparam as refeições e servem os patrões: as populações negras e as mulheres. Na cozinha, se trava uma batalha simbólica e se atualizam as contradições de uma sociedade que continua profundamente racista e desigual.

As ações implementadas pelo Estado, mecanismos suscetíveis de valorizar as culturas locais ou promover o turismo, expulsam a dimensão política do trabalho, escondem os conflitos sociais e raciais, aplanam a rugosidade do patrimônio e asseptizam a cultura (BROMBERGER, 2014, p. 146). A valorização dos saberes nativos, em particular os que estão relacionados à alimentação tradicional, tem consequências concretas para as populações locais inseridas num contexto de modernidade alimentar. Sem terem sido consultados, veem seus hábitos culturais expostos e caricaturados nos restaurantes-museus onde trabalham, e seus conhecimentos mais "naturais" - os saberes alimentares - serem transformados em sinais identitários. Não pleiteiam o reconhecimento das suas expressões culturais, agora folclorizadas, e das quais foram despossuídos (ABDALA, 2019). Os detentores desses patrimônios não são beneficiados, não são contemplados pelos processos de patrimonialização e devem se contentar com as migalhas do turismo. O reconhecimento da profissão pelo órgão cultural não aboliu as barreiras sociais e raciais, pelo contrário: as cozinheiras, como suas ancestrais, continuam trabalhando nas cozinhas das casas-grandes e preparam pratos de "comida regional" agora para os turistas e as famílias saudosas do tempero caseiro que se reúnem nos restaurantes gourmets da capital potiguar em dias de festa.

O exemplo do chouriço mostra, ao contrário, que o doce é uma exceção cultural, obedecendo a uma lógica não monetária e que não consegue ser padronizado para fins comerciais e turísticos. Mesmo se é supervalorizado localmente, é também dificilmente patrimonializável, pois é uma produção que, além dos entraves ligados às regras da vigilância sanitária, se destina a um consumo familiar, controlado por relações de confiança entre o produtor e o consumidor (POULAIN, 2002). A estranha patrimonialização que observamos no Seridó e o esquecimento do 
chouriço pelas instâncias estatais que deveriam proteger os saberes e as práticas a ele associadas revela ainda, desse modo, as contradições dos processos patrimoniais.

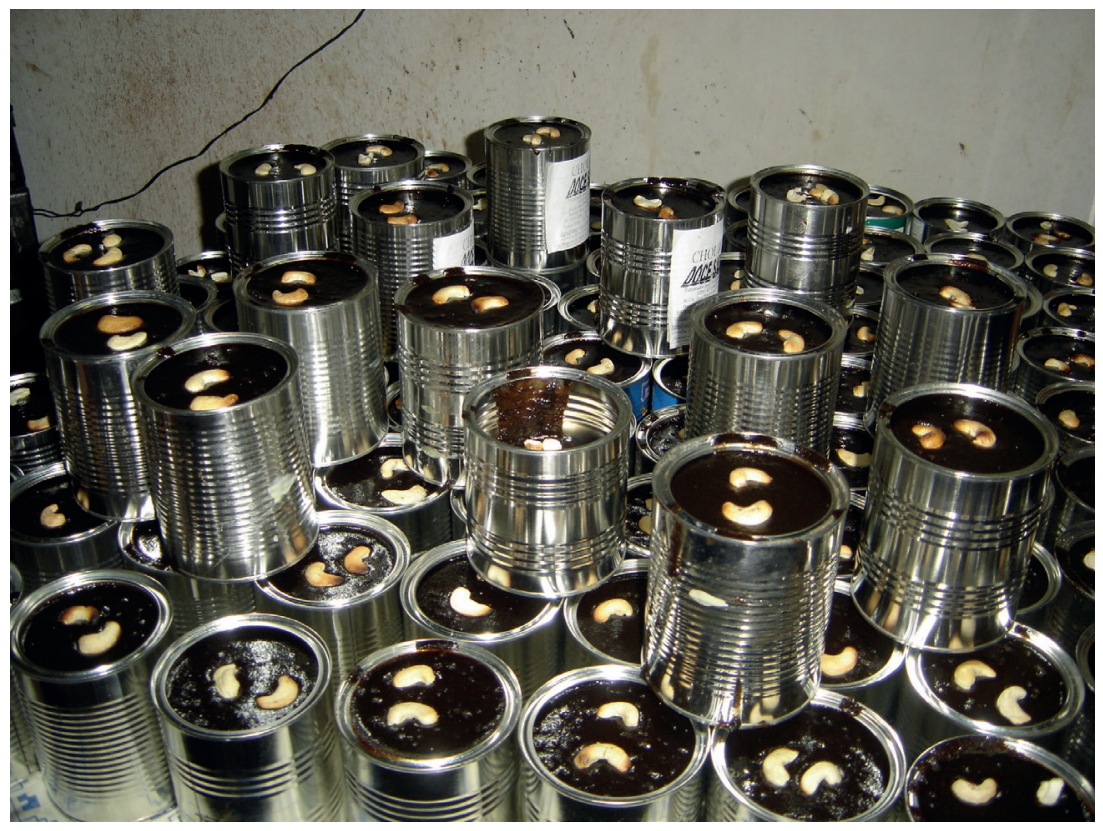

Latas de chouriço enfeitado. Foto: Isabel Dantas, 2008

\section{NOTAS}

1. O presente trabalho foi realizado com apoio do Conselho Nacional de Desenvolvimento Científico e Tecnológico (CNPq) e da Coordenação de Aperfeiçoamento de Pessoal de Nível Superior - Brasil (CAPES) - Código de Financiamento 001.

2. O Seridó norte-rio-grandense faz fronteira com a Paraíba, estado com quem mantém laços históricos e culturais fortes; é composto por 24 municípios, sendo Caicó a principal cidade, localizada na região centro-sul do estado, distante $256 \mathrm{~km}$ da capital Natal. A região interiorana do Nordeste brasileiro, o sertão, representa $20 \%$ do território nacional, e é um semideserto. A região é conhecida por suas secas regulares e por ter fornecido mão de obra ao Sudeste; os migrantes nordestinos são responsáveis pela construção dos grandes centros urbanos do país. Até os anos 2000, conhecia altos índices de pobreza e taxas elevadas de carência alimentar. O cenário mudou profundamente com as políticas públicas instauradas durante a era Lula (CÁSSIA, 2015).

3. O atual governo extinguiu o Ministério da Cultura em janeiro de 2019 e subordinou os institutos e as fundações de cultura ao Ministério do Turismo, pelo decreto presidencial número 10.108, assinado em 7 de novembro de 2019. Um professor universitário e também pastor da comunidade cristã Ministério Defesa da Fé, sr. Tassos Lycurgo, foi nomeado à frente do Departamento do Patrimônio Imaterial do IPHAN. Para uma análise do modelo de desenvolvimento do agronegócio, a participação de empresas multinacionais e sua influência nas políticas públicas, ver o artigo de Heredia, Palmeira e Leite Lopes (2010). 4. A reportagem pode ser consultada no link: <https://www.youtube.com/wat$\mathrm{ch} ? \mathrm{v}=\mathrm{euYrhF} 1 \mathrm{~S} 0 \mathrm{Nw}>$. 
5. O doutorado foi orientado por Julie Cavignac e defendido em 2008 no programa de Pós-graduação em Ciências Sociais da Universidade Federal do Rio Grande do Norte (DANTAS, 2008). As autoras participaram do Inventário da Cultura do Seridó, entre 2006 e 2008, realizado por uma equipe pluridisciplinar de discentes e docentes da Universidade Federal do Rio Grande do Norte e do Instituto Federal do Rio Grande do Norte, que serviu de base para a constituição do dossiê para o registro da Festa de Sant'Ana como celebração pelo IPHAN em 2010. Grande parte da etnografia foi realizada entre 2004 e 2008, nas festas comunitárias, nos sítios Carnaúba de Baixo, Olinda, Boa Vista, em pesquisas centradas sobre a doçaria. Posteriormente, as pesquisadoras coordenaram projetos de pesquisa e extensão, como o "Museu virtual Doces do Seridó", "Ações de patrimonialização do chouriço na comunidade Boa Vista", "Doçaria seridoense: um patrimônio cultural alimentar", "Patrimônios sensíveis: memórias locais, práticas, saberes naturalizados", o programa "Tronco, Ramos e Raízes" sobre os saberes das cozinheiras no âmbito rural e urbano, em particular na comunidade quilombola de Boa Vista (Parelhas), nas cidades de Acari, Jardim do Seridó, Carnaúba dos Dantas e Caicó (CAVIGNAC et al., 2010, 2016; DANTAS, 2008, 2012; IPHAN, 2011).

6. A identificação dos seridoenses com a culinária regional e, em particular, os doces, foi perceptível durante o I Festival de Doceiras do Seridó, em Caicó, em setembro de 2019, que reuniu um público local apreciador de doces.

7. Nas cidades grandes, o chá ou o café é uma ocasião de reunir colegas de trabalho e é uma forma de sociabilidade essencialmente feminina entre mulheres de uma mesma família ou amigas: comemoração, despedida de solteira, chá de bebê etc.

8. Blog do Perry, segunda-feira, 28 de março de 2011, Timbaúba - XIII. Disponível em: <http://peryserranegra.blogspot.com/search?updated=-max2011-04-06T23:20:00-03:00\&max-results=7>. Acesso em: 21 jan. 2021.

9. Usa-se, indiferentemente, umbu ou imbu. O umbuzeiro (nome científico: Spondias tuberosa) é uma árvore comum da caatinga.

10. Segundo Luís da Câmara Cascudo (2011, p. 356), o doce seco seria de origem portuguesa, da doçaria conventual: "a casca é a farinha de mandioca, fina, feito angu, seca, com outra porção de farinha para abrir o ponto. A espécie, recheio, é feita de farinha de mandioca, passada em peneira fina, gengibre, gergelim, castanha de caju, pimenta-do-reino, cravo, erva-doce e mel de rapadura. É um dos doces típicos na Noite de Festa, Dia do Natal, São João, São Pedro e Ano Novo".

11. Dona Zélia se reconheceu como quilombola ao evocar publicamente a história da sua avó, cozinheira famosa em Acari (CAVIGNAC et al., 2016). Mais detalhes podem ser consultados no Museu Virtual Doces do Seridó, disponível em: $<$ http://docesdoserido.com.br/index.html $>$.

12. Em Carnaúba dos Dantas, participamos de vários chouriços de Dona Angelita Maria Dantas, viúva, nascida em 1936, mãe de doze filhos nascidos e criados no sítio. Dona Daluz Dantas (in memoriam), casada, nascida em 1945, dez filhos, agricultora aposentada, vizinha de Dona Angelita, sempre criou porco no seu sítio. Dona Maria Luíza de Azevedo (in memoriam), nove filhos, nascida em 1936, residiu grande parte de sua vida na cidade de Jardim do Seridó e Dona Damiana Maria da Cruz, 5 filhos, nascida em 1939, no Sítio do Picuí, em Grotas, próximo de Nova Palmeira, na Paraíba, moradora da Boa Vista dos Negros, em Parelhas, foram também nossas interlocutoras. Em 2020, Dona An- 
gelita e Dona Daminha receberam o prêmio da Lei Aldir Blanc reconhecendo sua trajetória e seu saber-fazer.

13. O arrasto é o conjunto das partes do animal menos nobres, que não são vendidas. É composto pelo espinhaço, o fígado, o coração, os bofes, os rins, os mocotós, a cabeça, as tripas, os buchos, a garganta, o esôfago, a língua.

14. Mestre(a) é o nome dado às pessoas que detêm um conhecimento específico. É reconhecido pela comunidade por sua arte ou saber-fazer que, geralmente, transmite às novas gerações. É o caso da capoeira, dos folguedos e de muitos outros campos da cultura popular. Assim, Maria Ieda da Silva Medeiros, a Mestra Dadi de Carnaúba dos Dantas, conhecida pelos seus mamulengos, ou ainda Seu Expedito Seleiro, em Nova Olinda-CE.

15. Os parentes e vizinhos ajudam a criar o porco dando restos das refeições; também chamadas de lavagem de porco.

16. São chamados de "criação" ou "gado miúdo".

17. Não é fácil circunscrever o universo social dos participantes da festa. Marques (2015, p. 15) descreve a realidade sociológica das extensas parentelas do sertão pernambucano, descrevendo o papel das "genealogias [que] são a um só tempo efeito e instrumento de consolidação desse status coletivo".

18. Se distinguem de outros produtos em proveniência "do reino" (pimenta, queijo), que lembram a dependência da antiga colônia à Portugal.

19. Esse doce tem todos os ingredientes do chouriço, sem a banha e o sangue do porco: feito com gergelim, para dar a cor preta, necessita de apenas $1 \mathrm{~h} 30 \mathrm{de}$ cozimento. Serve de recheio para o doce seco, muito próximo do antigo fartem da Beira, farte, farten ou fartel português (CASCUDO, 2011, p. 318-319). Para uma análise das representações do Seridó pelas suas elites, ver a análise original de Muirakytan K. de Macêdo (2007, 2015).

20. Em 2016, 36,2\% da população do Rio Grande do Norte vivia abaixo da linha da pobreza, com menos de 5,5 dólares por dia e por pessoa. 72,9\% dos pobres são pretos ou pardos. Quase 59\% da população se declara negra ou parda (IBGE, 2017).

21. É um prato preparado com peixes de pequeno tamanho (ginga), servidos fritos numa tapioca; normalmente descartados pelos pescadores para venda.

22. É o Programa Nacional do Patrimônio Imaterial - PNPI, instituído pelo Decreto $\mathrm{n}^{\circ} 3.551$, de 4 de agosto de 2000, que viabiliza projetos de identificação, reconhecimento, salvaguarda e promoção da dimensão imaterial do patrimônio cultural.

23. O artigo 68 da Constituição Federal reconhece a dívida histórica da Nação brasileira em relação à escravidão, com o dever de emitir títulos de propriedade aos ocupantes dos territórios tradicionais. Remanescente de quilombos é o termo legal que corresponde aos diferentes grupos que se reconhecem numa trajetória histórica própria, relacionada com a resistência à opressão histórica sofrida. No entanto, o artigo constitucional foi regulamentado apenas em 2003, com a promulgação do Decreto 4.887. Quase vinte anos depois, constatamos que esse direito é de difícil aplicação, pois fere interesses econômicos dos proprietários de terra; a burocratização e a judicialização dos processos fundiários, bem como a incapacidade do Estado em fazer valer a lei, fez com que muito poucos quilombos tivessem seus títulos emitidos e que poucos documentos e monumentos fossem tombados.

24. Os bens registrados nas listas representativas da UNESCO são o Círio de Nazaré (Pará), o Frevo (Pernambuco), as Expressões Orais e Gráficas dos Wajãpis 
(Amapá), o Samba de Roda do Recôncavo (Bahia) e a Capoeira, em nível nacional. 25. No Sudeste, o queijo da serra da Canastra e Salitre, o Sistema agrícola do quilombo Vale do Ribeira; no Sul, os doces de Pelotas; no Norte, foi realizado um inventário das referências culturais ligadas ao sistema alimentar - cuias, tacacá, farinha de mandioca -, e foi registrado o sistema agrícola do Rio Negro; no Nordeste, houve registros dos processo de fabricação da Cajuína, do Acarajé (Ofício das Baianas de Acarajé). Para uma lista detalhada dos inventários realizados, ver a publicação do IPHAN (2018) e no site do IPHAN: <http://portal. iphan.gov.br/pagina/detalhes/681/>.

26. O atual prefeito da cidade do Natal, Álvaro Dias, que revitalizou o Beco da Lama (foi declarado Patrimônio Cultural da cidade, em 17/06/2021, pela Comissão de Educação, Cultura, Ciência, Tecnologia e Inovação da Câmara Municipal de Natal), lugar de referência para a boemia e gastronomia da cidade de Natal, fez campanha para demolir o antigo Hotel Internacional dos Reis Magos, de estilo modernista, inaugurado em 1965. O hotel foi demolido em dois dias, no final do mês de janeiro de 2020, apesar dos protestos da sociedade civil organizada. Segundo o prefeito, o prédio não tinha valor histórico e representava um obstáculo ao desenvolvimento da orla urbana. O projeto é construir, no local, um bairro moderno, o que provavelmente irá excluir os moradores das casas populares do bairro.

27. O projeto foi aprovado pelo SEBRAE e contou com a parceria do SENAC, SESI e IFRN.

28. Parecer do Conselho consultivo, Processo No 01450.004974/2008-26: $<$ http://portal.iphan.gov.br/uploads/ckfinder/arquivos/Parecer_conselho_ consultivo_festa\%20de\%20santana_de_caico.pdf $>$. Importante ressaltar que a equipe que realizou o Inventário das Referências Culturais do Seridó, da qual as autoras participaram, não foi a mesma que elaborou o dossiê nem o plano de salvaguarda. Em 2020 deveria ter sido realizado a pesquisa para revalidação do título mas, devido à pandemia, foi adiado. Em 2021, foi o próprio órgão que se responsabilizou pela elaboração da proposta de revalidação, sem que houvesse nenhum tipo de publicização.

29. A referência ao chouriço desaparece das ações de salvaguarda no documento elaborado pelo IPHAN em 2018 (p. 2013-2014).

30. Sobre trajetórias de cozinheiras negras e a presença histórica e cultural dos afrodescendentes no Seridó, ver Cavignac (2010) e Cavignac e Macedo (2016). 31. No Rio Grande do Norte, em 2014, das 984 famílias quilombolas, 72,7\% ganhava até R\$154,00 (BRASIL, 2014, p. 82).

\section{REFERÊNCIAS}

ABDALA, Mônica. Práticas sustentáveis temperadas por memórias e experiências. Revista Ingesta, São Paulo, n. 1, v. 1, p. 159-171, mar. 2019. ADELL, Nicolas; POURCHET, Yves (org.). Transmettre, quel(s) patrimoine(s):

Autour du patrimoine culturel immatériel. Paris: Michel Houdiard, 2011. BOURDIEU, Pierre. La distinction. Paris: Les Éditions de Minuit, 1979.

BRASIL. Ministério do Desenvolvimento Social e Combate à Fome.

Quilombos do Brasil: segurança alimentar e nutricional em territórios titulados. In: PINTO, Alexandre Rodrigues; BORGES, Júlio Cé- 
sar; NOVO, Marina Pereira; PIRES, Pedro Stoeckli (Org.). Brasília: Ministério do Desenvolvimento Social e Combate à Fome; Secretaria de Avaliação e Gestão da Informação, 2014.

BROMBERGER, Christian. Le patrimoine immatériel entre ambiguïtés et overdose. L'Homme, n. 209, p. 143-151, 2014.

BORTOLOTTO, Chiara. Patrimônio e o futuro da autenticidade. Revista do Patrimônio Artístico e Histórico Nacional, n. 36, p. 23-37, 2017.

CASCUDO, Luís da Câmara. História da Alimentação no Brasil. 3 ed. Belo Horizonte: Itatiaia; São Paulo: Editora da Universidade de São Paulo, 2011.

CASSIA, Rita de. Políticas públicas no Nordeste do Brasil: a produção de enclaves e de desigualdades socioespaciais. GOT - Revista de Geografia e Ordenamento do Território, n. 8, p. 11-31, 2015.

CAVIGNAC, Julie A.; OLIVEIRA, Luiz Antônio de; CASCUDO, Luís da Câmara. In: Jean Pierre Poulain (org.). Dictionnaire des cultures et des modèles alimentaires vol. 1. 1. ed. Paris: Puf Collection Quadrige, 2012. p. 226-232.

CAVIGNAC, Julie A. Patrimônio cultural e questão étnica no Rio Grande do Norte. In: BARRIO, Angel Espina; MOTTA, Antonio; GOMES, Mário Hélio (org.). Inovação cultural, Patrimônio e Educação vol. 1.1 ed. Recife: Massangana, 2010. p. 107-128.

CAVIGNAC, Julie; MACÊDO, Muirakytan K. de. Tronco, ramos e raízes! História e patrimônio cultural do Seridó negro. Natal: EDUFRN, 2016. Disponível em: <https://repositorio.ufrn.br/jspui/handle/123456789/21376>. Acesso em: 11 out 2021.

CONTRERAS, Jesús; GRACIA, Mabel. Alimentación y cultura: perspectivas antropológicas. Barcelona: Ariel, 2005.

CONTRERAS, Jesús. A modernidade alimentar: entre a superabundância e a insegurança. História: Questões \& Debates, Curitiba, n. 54, p. 19-45, jan./jun. 2011. Disponível em: <https://revistas.ufpr.br/historia/article/view/25736/17194>.

CUNHA, Maria Manuela Ligeti Carneiro da. Cultura com aspas: e outros ensaios. São Paulo: Cosac \& Naify, 2009.

DANTAS, Maria Isabel; CARVALHO, Cynthia Melo de. Doçaria do Seridó potiguar e economia da cultura. In: VII CONNEPI - Congresso Norte Nordeste de Pesquisa e Inovação, 66. Anais... 2012. Disponível em: <https://propi.ifto.edu.br/ocs/index.php/connepi/vii/paper/ view/5091>.

DANTAS, Maria Isabel. O sabor do sangue: uma análise sociocultural do chouriço sertanejo. 2008. 365 f. Tese (Doutorado em Ciências Sociais) - Universidade Federal do Rio Grande do Norte, Natal-RN, 2008. Disponível em: <https://repositorio.ufrn.br/jspui/bitstream/123456789/13685/1/SaborSangueAnálise_Dantas_2008.pdf>.

FABRE-VASSAS, Claudine. La bête singulière: les, juifs, les chrétiens et le cochon. Paris: Gallimard, 1994.

FARIA, Oswaldo Lamartine de. Ferros de ribeiras do Rio Grande do Norte. Fortaleza: Imprensa Universitária, 1984. 
FISCHLER, Claude. Pensée magique et alimentation aujourd'hui. Paris: Cahiers de l'OCHA 5, 1996.

FREYRE, Gilberto. Casa-Grande e Senzala. 34 ed. Rio de Janeiro: Record, 1998.

GONÇALVES, José Reginaldo Santos. Mal-estar no patrimônio: identidade, tempo e destruição. Estudos Históricos, Rio de Janeiro, v. 28, n. 55, p. 211-228, jan./jun. 2015.

HEREDIA, B. M. A.; PALMEIRA, M.; LEITE, S. P. Sociedade e economia do agronegócio. Revista Brasileira de Ciências Sociais, v. 25, p. 159-176, 2010.

IBASE - INSTITUTO BRASILEIRO DE ANÁLISES SOCIAIS E ECO-

NÔMICAS. Repercussões do Programa Bolsa Família na segurança alimentar e nutricional das famílias beneficiadas - Documento Síntese. Rio: IBASE, 2008. Disponível em: <https://ibase.br/userimages/ ibase_bf_sintese_site.pdf $>$. Acesso em: 12 jun. 2018.

IBGE - INSTITUTO BRASILEIRO DE GEOGRAFIA E ESTATÍSTICA. Pesquisa Nacional por Amostra de Domicílio. Rio de Janeiro: IBGE, 2009. IICA - INSTITUTO INTERAMERICANO DE COOPERAÇÃO PARA A AGRICULTURA. Plano de desenvolvimento sustentável da região do Seridó do Rio Grande do Norte vol. 1: diagnóstico do Conselho de Desenvolvimento Sustentável do Seridó. 2000. Disponível em: $<$ http://www.iica.org.br/Docs/Publicacoes/PublicacoesIICA/PlanoDesenvolvimentoSustentavelSeridó-VolumeI.pdf>.

IPEA - INSTITUTO DE PESQUISA ECONÔMICA APLICADA. Pesquisa e Planejamento Econômico, Brasília: Ipea, v. 46, n. 1, 2016. Disponível em: <http://repositorio.ipea.gov.br/bitstream/11058/6490/1/ PPE_v46_n01.pdf>. Acesso em: 23 abr. 2018.

IPHAN - INSTITUTO DO PATRIMÔNIO HISTÓRICO E ARTÍSTICO NACIONAL. Dossiê Iphan. A festa de Sant’Ana. Brasília: Ministério da Cultura/Iphan/Mec, 2011. Disponível em: <http://www. iphan.gov.br>. Acesso em: 04 jan. 2018.

IPHAN - INSTITUTO DO PATRIMÔNIO HISTÓRICO E ARTÍSTICO NACIONAL. Saberes, fazeres, gingas e celebrações: ações para a salvaguarda de bens registrados como patrimônio cultural do Brasil 20022018. Brasília: IPHAN, 2018. Disponível em: < http://portal.iphan.gov. br/uploads/publicacao/sfgec.pdf >. Acesso em: 20 jan. 2019.

LÉVI-STRAUSS, Claude. Mythologiques: le cru et le cuit. Paris: Plon, 1964.

LIMA Filho, Manuel F. Da matéria ao sujeito: inquietação patrimonial brasileira. Revista de Antropologia, v. 52, n. 2, p. 606-632, 2009.

MACÊDO, Muirakytan Kennedy de. A penúltima versão do Seridó: uma história do regionalismo seridoense. Natal: Sebo Vermelho, 2007.

MACEDO Muirakytan K. de. Rústicos cabedais: patrimônio e cotidiano familiar nos sertões do Seridó (séc. XVIII). Natal: EDUFRN, 2015.

MARQUES, Ana C. Movimentos em Família. RURIS - Centro de Estudos Rurais, v. 9, n. 1, 2015. Disponível em: <https://www.ifch.unicamp.br/ojs/index.php/ruris/article/view/2074>. 
MINTZ, Sidney. Comida e antropologia: uma breve revisão. RBCS, v. 16, n. 47, out. 2001.

MORAIS, Ione Rodrigues Diniz; DANTAS, Eugênia Maria. Região e capital social: a reinvenção do Seridó nos fios silenciosos da cultura. In: III SEMINÁRIO INTERNACIONAL SOBRE DESENVOLVIMENTO REGIONAL, Santa Cruz do Sul, 2006. Disponível em: <https://www. unisc.br/site/sidr/2006/textos3/21.pdf>. Acesso em: 12 abr. 2019.

PESTEIL, Philippe. Questions de goûts et de couleurs: les variantes agro-alimentaires en Corse à l'épreuve de la certification. Journal des anthropologues, 2006. Disponível em: <http://jda.revues.org/1232>. Acesso em: 09 nov. 2014.

POULAIN, Jean-Pierre. Manger aujourd'hui. Attitudes, normes et pratiques. Editions Privat: Paris, 2002. Disponível em: <http://www.lemangeur-ocha.com/wp-content/uploads/2012/05/02_Introduction.pdf $>$.

POULAIN, Jean Pierre (org.). Dictionnaire des cultures alimentaires. Paris: PUF, 2012.

POULAIN, Jean Pierre. Sociologias da alimentação: os comedores e o espaço social alimentar. 2 ed. Florianópolis: Editora da UFSC, 2013.

SANTOS, Jardelly Lhuana da Costa. Um rastro de memória: terra, parentesco e ofícios na família Belém em Acari/RN (séc. XVIII-XXI). Dissertação (Mestrado em Antropologia Social) - Centro de Ciências Humanas, Letras e Artes, Universidade Federal do Rio Grande do Norte, Natal, 2017.

SANTOS, Sebastião Genicarlos. Parentes, vizinhos e compadres: estratégias de resistência e relações interraciais na Boa Vista dos negros. Dissertação (Mestrado em Antropologia Social) - Centro de Ciências Humanas, Letras e Artes, Universidade Federal do Rio Grande do Norte, Natal, 2020.

SILVA, Danycelle Pereira. Os fios da memória: presença afro-brasileira em Acari nos tempos do algodão. Dissertação (Mestrado em Antropologia Social) - Centro de Ciências Humanas, Letras e Artes, Universidade Federal do Rio Grande do Norte, Natal, 2014.

TIBERE, Laurence. Alimentation et vivre-ensemble: le cas de la créolisation. Anthropologie et Sociétés, v. 37, n. 2, p. 27-43, 2013.

VELHO, Gilberto. Patrimônio, negociação e conflito. Mana, n. 12, v. 1, p. 237-248, 2006.

VILÁ, Mirian Bertran; VASQUEZ-MEDINA, José Antonio. Modernidad a la carta: manifestaciones locales de la globalización en México. Barcelona; Xochimilco: Icaria/ Observatório de la alimentación/ Universidad Autónoma Metropolitana, 2018.

WOORTMANN, Ellen. Herdeiros, parentes e compadres: colonos do Sul e sitiantes do Nordeste. São Paulo: Hucitec; Brasília: EdUnB, 1995.

WOORTMANN, Ellen. F. A comida como linguagem. Habitus, Goiânia, n. 11, v. 1, p. 5-17, 2013. 